Владан Гавриловић

Универзитет у Новом Саду

Филозофски факултет

Одсек за историју

gavra1@yahoo.com
Оригиналан научни рад

примљено: 12. април 2012

прихваћено: 1. октобар 2012

\title{
МИГРАЦИОНА КРЕТАЫА СРПСКОГ НАРОДА У БОСНИ У ВРЕМЕ ВЕЛИКОГ БЕЧКОГ РАТА
}

Сажетак: У време Великог бечког рата дошло је до великих миграционих кретања на Балканском полуострву, поготово из Босне у Хрватску и Славонију. Претежно се радило о Србима који су масовно прелазили с турске на аустријску територију, али су забележени и католици из Босне. Насељени су ратом опустели делови Лике, Крбаве, као и централни делови Славоније, који су се сви нашли под влашћу Аустрије. У овом периоду од 1683. до 1699. више десетина хиљада православних и католика је избегло из Босне, на просторе Хабзбуршке монархије што је знанто ојачало већ постојећи српски корпус у Монархији.

Кључне речи: Хабзбуршка монархија, Велики бечки рат, Срби, Босна, Хрватска, Славонија, католици, миграције.

У историји миграционих кретања на централном делу Балакана и средњег Подунавља Велики бечки рат $\left(1683\right.$ - 1699) је означио судбоносну прекретницу. ${ }^{1}$ Од унутрашњег померања изазваног кретањем сточара „Влаха“ као и насилног пресељавања становништва, које су вршиле турске власти, прешло се на исељавање из Турске царевине, посебно из Босне, Херцеговине, Србије и Македоније, у земље које су већ одраније биле у саставу Хабзбуршке монархије, као што су :

\footnotetext{
* Текст је настао као фазни резултат рада на пројекту Војвођански простор у контексту европске историје (број 177002) Министарства просвете и науке Републике Србије.

${ }^{1}$ О Великом бечком рату и Карловачком миру види радове : Душан Ј. Поповић, Слика Војводине у 18 веку, Војводина II, Нови Сад, б. г, 86-111; Исти, Племсто, Војводина II, 111-138; Глигор Станојевић, Србија у време Бечког рата, Београд 1976; Душан Ј. Поповић, Историја Срба у Војводини, къ. II, Нови Сад 1990; Никола Самарџић, Франиуска и Турска (1687-1691), Београд 1992; Алекса Ивић, Историја Србау Војводини, Нови Сад 1996 (поновљено издање); Жарко Димић, Велики бечки рат и Карловачки мир, Београд 1999; Дејан Микавица-Владан Гавриловић-Горан Васин, Знаменита документа за историју српског народа (1538-1918), Нови Сад 2007, 25-41; Дејан Микавица, Српско питање на угарском сабору, Нови Сад 2011, 11.
} 
најзападнији делови Хрватске и северне Угарске, а још више у оне које је Монархија освојила у овом рату од Турске (преостале делове Хрватске и Славоније). Од тог доба миграције су добиле вид пребегавања из Турске у аустријску државу, које ће Аустрија драге воље прихватити и од избеглих Срба „Влаха“, са једне стране, попунити свој већ донекле изграђени одбрамбени систем према Турској, односно систем Војних граница, а са друге стране Србима попунити феудалне, односно коморске и спахијске поданике на тим територијама.

Цео ток Великог бечког рата праћен је расељавањем и сеобом становништва, како хришћанског тако и муслиманског. Почело је још на самом почетку рата, 1683. године напуштањем хришћана, најчешће Срба, њихових насеља крај путева којима се кретала турска војска према Бечу, односно делимичног напуштања простора Срема, Источне Славоније и Барање. ${ }^{2}$ У отприлике исто време, 1683 - 1685, на миграцију, испод турске под аустријску власт, покренули су се многи Срби из турског дела Лике, Крбаве и из Босне, највише у аустријски део Лике и покупску Банску крајину. ${ }^{3}$ Према писању аустријјског етнографа и историчара Цернига, само у току 1684. године у Хрватску војну границу (Карловачки генералат) тим путем се у њој нашло (населило) око 4.000 Срба. ${ }^{4}$

Ратне операције против Турака на простору јужно од Саве почеле су 1685. године. Тада су Срби из Босне послали изасланике бану Николи Ердедију да се договоре око њиховог масовног пресељења на аустријску страну, после чега је средином јуна те године уследило „заштитно писмо“ цара Леополда I српском становништву, услед чега је дошло до пресељења више Срба на аустријску страну.

Генерал аустријске војске гроф Херберштајн водио је борбе у турској Лики од 1685. до 1686. године и у том периоду велики број Срба, неколико хиљада, како бележе извори, је пребегло на аустријску страну. Када је овај део Лике коначно запоседнут 1690. године од стране аустријске војске, у њега су, с обзиром да је био слабије насељен, похрлили многи Срби из Далмације и Босне. Они из Далмације насељени су у Зрмању и Грачац, они из Босне (Купреса) на рубни појас Крбаве, а Срби насељени у хришћанском делу Лике су се померили према новоосвојеним личким (турским) подручјима. ${ }^{5}$ На тај начин је оформљена етничка структура Лике,

\footnotetext{
${ }^{2}$ Рајко Веселиновић, Народни покрети и устанции, у Историја српског народа, књ. ІІІ, Београд 1993, 491 492.

${ }^{3}$ Исто, 495, 498.

${ }^{4}$ Церниг помиње и насељавање преко 5.000 душа хрватског становништва 1683. у многе опустеле делове Војне границе, које је вероватно као и српско пореклом из Босне. У оригиналу Цернигов запис о насељавању 1683. и 1684. у подручје Хрватске војне границе (Карловачког генералата) гласи : 1683 Mehrere entvölkerte Orte wurden mit 5800 frischen kroatischen Ansiedlern vermehrt. 1684- Dasselbe geschah mit 4.000 Serben. (Karl Freiherr v. Czoernig, Etnographie der Oesterreichischer Monarchie, II Band, Wien 1857, 305)

${ }^{5}$ Како наводе извори, Хербештајн се вратио из похода заробивши много Турака и превевши на аустријску страну 180 српских породица, односно 1459 душа из Перушића, Бунића и околних места, које су се населиле у Брињу и околини. Почетком 1786. У Баг (Картлобаг) избегла је група од око 500 Срба, а Срби, њих преко 200, са подручја Кладуше су се такође нашли на том ослобођеном делу Лике. (Алекса Ивић, Миграиије Срба у Хрватску током 16, 17. и 18. столећа, Суботица 1926, 154 - 155 ; Манојло Грбић, Карловачко владичанство, књ. I, (репринт издање), Топуско 1990, 74, 78)
} 
у којој су Срби, према наводу сењског бискупа Мартина Брајовића из 1702. године, били „највећи народ“ настањен у компактним целинама са својим црквама и свештенством. ${ }^{6}$ Пораст становништва Лике, односно број „влашких“ српских обитељи у њој бележе и аустријски историчари. Према једном од њих, Карлу Казеру, број срспких породица нагло је порастао у Лици у годинама између 1696. и 1712, па су Срби чинили преко 70 \% укупног становништва. Друга најбројнија скупина били су Хрвати са нешто више од $14 \%$, док су око 9\% чинили Буњевци. ${ }^{7}$ Овакве податке је изнела посебна царска комисија која је 1712. године извршила попис становништва Лике и Крбаве при њиховом коначном укључењу у Карловачки генералат. При томе је утврђено да је 35 насеља у Лици и Крбави имало укупно 26.503 становника, од чега су Срби чинили 20.500, док је католика било 6.003 , али са посебном напоменом да су различитог етничког порекла, односно Хрвати и Буњевци. ${ }^{8}$ Већина Срба на том простору, чак 93, 46\%, односно 19.159, је живело у етничким чистим српским насељима: Брувну, Бунићу, Дивоселу, Грачацу, Јошанима, Кореници, Мазину, Медаку, Мекињару, Могорићу, Островици, Пећанима, Пишаћу, Плочи, Почитељу, Попини, Радучу, Средњој Гори, Широкој Кули, Висућу, Вребцу, Звониграду (Зрмањи). ${ }^{9}$

Досељавања у Лику било је и после Великог бечког рата, али је оно било у пуно мањем обиму јер је понестало слободне обрадиве земље у Лици, па је до повећања становништва у XVIII веку долазило више путем природног прираштаја. ${ }^{10}$

Исто тако, у току Великог бечког рата, доста Срба насељено је на Кордуну, углавном од 1686. године и надаље. Срби из Босне (Кладуше, Цазина) насељени су у том периоду у Војнић и околину. ${ }^{11}$ Ситуација на Кордуну није била у потпуности решена, Турци су само потиснути са тзв. „ничијег подручја“, задржавши све време рата важне стратешке тачке као што су Цетин и Дрежник. ${ }^{12}$ Но на тој ничијој земљи полако је текло насељавање. Рецимо барон Фрањо Оршић, турањски капетан, извео је Србе из Кладуше и населио око Будачког и Коларића, као и Србе из Острошца и Цазина, које је распоредио по Перјасици и Тржићу. Око Будачког насељено је још 100 породица које је генерал Херберштајн 1685 . превео из турске Лике. ${ }^{13}$ Кордун је попуњаван српским становништвом из Босне и после завршетка Великог бечког рата, односно већ 1700. године избегло српско становништво из Босне насељено у

\footnotetext{
${ }^{6}$ Radoslav Lopašić, Spomenici hrvatske krajine, knj. III, Zagreb 1889.

${ }^{7}$ Karl Kaser i saradnici, Popis Like i Krbave 1712. godine, Zagreb 2003, 20.

${ }^{8}$ Војин Дабић, Војна крајина, Карловачки генералат (1530-1746), Београд 2000, 125.

${ }^{9}$ Исто, 125-126.

${ }^{10}$ Исто, 126.

11 Забележено је да је генерал Матија Штрасолдо после заузећа Будачког утврдио то место и у њега и његову околину, највише у Војнић, населио 284 српске породице са 2.784 лица од којих 747 наоружаних пешака, 184 коњаника и још 294 способних за оружје. Radoslav Lopašić, Oko Kupe i Korane, Zagreb 1895, 98, 266.

12 Цетин као важно турско утврђење је пао тек у последњем аустро-турском рату (1788-1791), чиме је коначно у потпуности Кордун потпао под аустријску власт. (Милан Радека, Кордун у прошлости, Загреб 1989, 51-53)

${ }^{13}$ Radoslav Lopašić, Oko Кире і Когапе , 98; Алекса Ивић, Миграиије Срба у Хрватску, 153; Манојло Грбић, нав.дело, књ. 1, 79-80.
} 
Кремен код Слуња и у Крстање и потчињено крајишком капетану у Крижанић Турњу. ${ }^{14}$ Још једно веће насељавање српског становништва на Кордун забележено је у више наврата у другој деценији XVIII века, односно 1711, 1713, 1716. и 1717. године. ${ }^{15}$

У току Великог бечког рата, посебно од 1687. до 1689. године Срби из Босанске крајине су у „огромним масама“ избегавали у Банију, где су насељавани од стране банских и каптолских власти. На тај начин насељени су Србима Кирин, Бовић, Топуско и друга мања места у Банској крајини. ${ }^{16}$ Тако је загребачки бискуп Берковић 1699. под својом ингеренцијом имао преко 4.000 Срба поданика. ${ }^{17}$ Још већа скупина Срба из Босанске крајине прешла је на аустријску страну, на Банију, после освајања Костајнице у току 1688 . године. ${ }^{18}$ После склапања Карловачког мира (1699) забележена је још једна велика миграција Срба из Босне у Банију, тачније од 1701. до 1703. године, када су се у Банску крајину пребацили многи Срби из околине Новог, који је Аустрија морала вратити Турској по слову уговора. Насељени су Мајске пољане, Класнић, Жировац, те је њихов број у доњој Банији прешао 11.000 душа. ${ }^{19}$ У то време српско избегличко становништво из Босанске крајине попунило је и ранија, умногоме опустела српска села на спахилуку Стеничњак гфрофовске породице Драшковић. ${ }^{20}$

У току Бечког рата до миграционих кретања дошло је и у Славонији, коју су 1684 - 1685. године почели ослобађају аустријске и хрватске (претежно српске, крајишке) снаге. У то време, као је писао из Беча децембра 1684. угарски палатин Пал Естерхази, половину становништва Славоније (medietas illarum Partium) чинили су „Власи и Расцијани“ односно Срби. ${ }^{21}$

У Славонију су 1687. избегли и босански Шокци, католици. Они су под вођством фрањеваца из Модриче прешли у Костајницу а са простора Дервенте и Прњавора дошли су на простор око Вировитице и Осека. Нешто касније босански Шокци мигрирали су и у Барању, а највише их је долазило из околине Сребренице а

\footnotetext{
${ }^{14}$ Алекса Ивић, Миграције Срба у Хрватску, 157, 170.

${ }^{15}$ Године 1711. капетан у Бариловићу у Босни је превео на аустријску страну у Корански брег, Косирско село и Козинац 158 српских породица са доста коња и оружја. Ускоро потом, 1713. много Срба избеглих из Босне је насељено око Клокоча, а 1717. нови талас је насељен у Клокоч и село Крстиње. (Radoslav Lopašić, Oko Kupe i Korane, 33, 42, 152; Манојло Грбић, нав.дело, књ.1, 80; Војин Дабић, Карловачки генералат, 112-113)

${ }^{16}$ Алекса Ивић, Мигращије Срба у Хрватску, 153 ; Манојло Грбић, нав.дело, књ. I, 94.

${ }^{17}$ Исто.

${ }^{18}$ Алекса Ивић, Мигращије Срба у Хрватску, 153; Манојло Грбић, нав.дело, књ.1, 91-92; Војин Дабић, Банска крајина 1688-1751, Београд-Загреб 1984, 57.

${ }^{19}$ Алекса Ивић, Миграчије Срба у Хрватску, 155-156; Манојло Грбић, нав.дело, књ.1, 94; Војин Дабић, Банска крајина, 57.

${ }^{20}$ Radoslav Lopašić, Oko Kupe i Korane, 291; Slavko Gavrilović, Prilog istoriji seljačkih nemira u Pokuplju od kraja XVII do kraja XVIII stoleća, Historijski zbornik, br. XVI, Zagreb 1963, 107.

${ }^{21}$ Magyar Orsagos Leveltal (MOL), A - 21, Litterae Palatinorum, cs. 2.
} 
насељавани су у околину Мохача и Печуја, да би се у тим крајевима повећао проценат католичког живља. ${ }^{22}$

Освајањем централне, источне Славоније, Срема, Бачке, а посебно Осека и Петроварадина до краја 1687. године, миграције из Босне кренуле су и у овом правцу. Септембра 1687. поход на ове крајеве су извршили гроф Јован Хајнрих Диневалд и гроф Иван Драшковић. ${ }^{23}$ Овоме је претходило „заштитно писмо“ (Littera Protectionale) којим је цар Леополд I хришћане у Босни позвао у борбу против Турака, обећавши им поред своје заштите, поштовање права и привилегија, слободе вере, што се свакако, првенствено, односило на тамошње православне Србе. ${ }^{24}$ После заузимања Осека од стране аустријске војске 1687. разуларени Турци и Татари, у повлачењу према Београду, опустошили су делове Срема, а највише фрушкогорске манастире и српске цркве, због чега је преко 10.000 душа под вођством хоповског игумана Илариона своје спасење потражило у Влашкој, да би пред крај 1688. молили за слободан повратак у свој завичај. ${ }^{25}$

Успешно ратовање царских трупа, са активним учешћем српских чета у њему, окончано је 1687. заузимањем Петроварадина, као и досељавањем Буњеваца на подручје Баје, Суботице и Сомбора. Подаци о овој буњевачкој сеоби врло су оскудни. Историограф Иштван Ивањи бележи да су се Буњевци доселили у Бачку „у јесен 1687“ те да их је предводило 19 фратара - фрањеваца као групацију која је бројала близу 5.000 душа. Према Ивањију и Ивићу од тих пресељеника, њих 1.500 је било способно за оружје. Звани су од стране царских власти као Раци - католици с подручја Босне и Далмације. Забележено је такође да су их предводила двојица капетана Дујо Марковић и Јуро Видаковић. Извори опет бележе да ни по коју цену нису желели да управу над њима имају мађарски него само немачки официри, будући да су им Мађари одузели чак и храну одмах пошто су прешли на аустријску територју. ${ }^{26}$ Према Јовану Радонићу после пораза Турака у Мађарској и Славонији 1686-1687, када је Босна и Херцеговина остала без регуларних турских трупа и била препуштена себи од стране тада немоћне Порте, а Млечани настојали да заузму градове у Херцеговини, католички фрањевци, у страху од Млечана, покренули су акцију да народ поведу на север, кроз потпуно дезорганизовану турску територију

\footnotetext{
${ }^{22}$ Krunoslav Tkalac, Porijeklo i kretanje Šokaca iz Bosne prema sjeveru preko Save i Dunava, Županijski zbornik, sv. 3, Županja 1971, 77 - 78.

${ }^{23}$ Tade Smičilkas, Dvijestogodišnjica oslobođenja Slavonije, Zagreb 1891, 124-129; Алекса Ивић, Миграџије Срба у Хрватску, 117-118; Рајко Веселиновић, нав.дело, 498-499.

${ }^{24}$ Славко Гавриловић, Извори о Србима у Угарској с краја XVII и почетка XVIII века, књ. II, Београд 1990, 24-25.

${ }^{25}$ О том погрому фрушкогорских манастира остао је сачуван запис : Оле тогда опустеше многи монастири и огнем сагореше 4 лаври : монастир Хопово и Милешева, Рача и Раваница. В том месте многи иноци томленије мача пријеше. (Славко Гавриловић, Извори о Србима у Угарској с краја XVII и почетка ХVIII века, књ. II, 40-41; Душко М.Ковачевић, Старо Хопово-манастир Светог Пантелејмона, Београд 2003, 30)

${ }^{26}$ Осим Ивањијевог дела из 1886. године о Буњевачкој сеоби писали су : Иван Иванић, Буњевцฺи и Шокии, Београд 1899, 68 - 69 ; Алекса Ивић, Историја Срба у Војводини, 267 - 268, 484 - 485; Јован Ердељановић, О пореклу Буњеваиа, Бероград 1930, 5-19;; Јован Радонић, О сеоби Буњеваиа у Суботииу 1687. године, Глас САНУ, CСXIV, Одељење друштвених наука, књ. 3, Београд 1954, 119 - 127.
} 
ка аустријским трупама у Славонији, а потом у Бачкој. Цраски командант у Шиклошу се сагласио са тим фрањевачким предлогом и препоручио Дворском ратном савету у Бечу 9. јула 1687 . да се тим „Католичким Рацима“ дозволи прелазак и подизање три паланке и насељавање у њима. Радонић закључује да се оваква Сеоба кроз босанску (турску) територију могла извести, само захваљујући потпуној дезорганизованости Турака. ${ }^{27}$

Како су се операције аустријске војске пребацивале ка Србији и Ердељу и у тим крајевима је започето померање становништва, што ће с обзиром на наслов нашег рада остати по страни. Наравно да је највећи миграциони талас била Велика сеоба Срба 1690. године, која ће с обзиром на наслов нашег рада остати по страни и добити своје истакнуто место у једној посебној студији.

Према истраживањима Алексе Ивића мигрирање из Босне наставило се и у току зиме 1687/1688. године а мигранти су насељавани на простор око Ђакова у Славонији и Дарде у Барањи. У току марта 1688. цело једно село са стотинак становника прешло је у Славонију. ${ }^{28}$

У намери да још више ослаби Турке у Босни и повећа насељавање Славоније, цар Леополд I je 11. јуна 1689. босанским хришћанима упутио позив за прелазак у Славонију, обећавши им своју заштиту и трогодишње ослобађање од дажбина и терета (ab omnibus tributis, Tiachis, laboribus, datys, alysque oneribus), осим од бесплатног кулука неопходног за одржавање границе. У погледу давања десетине од урода и природа били би прве године сасвим ослобођени, а друге године би давали само двадесетнину, а треће петнаестину. Такође би у току три године плаћали само половину царине и тридесетнине на промет роба и својих производа. ${ }^{29}$ По наводима примаса Угарске кардинала Леополда Колонића доста хришћана је из Босне прешло те године у Славонију, али им аустријске власти нису довољно помогле, те су многи од глади помрли. ${ }^{30}$ Узимајући ово све у обзир Алекса Ивић је констатовао „да се оваквих вести о пресењу Срба из Босне у Славонију налази много током 1688. и 1689, те да је знатан број становника из Босне па чак и из Србије пресељен раније, независно од патријархове Сеобе и8 насељен у домовима и местима које су Турци напустили“. Као конкретан пример навео је како је крајем 1689. или почетком 1690. један командант царске војске напао на доњу Тузлу (Соли) код Сарајева побио 300-400 Турака и 1.500 Срба (Ratzen) превео у Славонију. ${ }^{31}$

\footnotetext{
${ }^{27}$ Јован Радонић, О сеоби Буњеваца у Суботииу 1687. године, 119 - 127.

${ }^{28}$ Алекса Ивић, Миграчије Срба у Славонију током 16, 17. и 18 столећа, Суботица 1926, 119, 121.

${ }^{29}$ Hoff Kriegs Archiv, Hoff Finanz Ungarn, (HKA, Hoff Ungarn), r.N ${ }^{\circ}$ 325, September 1688, fol.230-233.

${ }^{30}$ Исељавање из Босне било је подстакнуто и великом глађу која је захватила и друге области под Турцима. Према оновременом запису босанског фрањевачког хроничара, тог лета „једоше људи месо пасје и човечје и коњско и много нечисто... И силан наросд помре у великој муци...Куд год би се мако лежаху мртци, нит се копаху, нит имадиаше ко...Јиђаху ресу липову, з дрвја кору, винову лозу, псе, мачке...А у то вриме паша [у Бањој Луци] сицијаше и вишаше и ускоке и рају, кога год би довели, и те мартце све изили“ (Иван Иванић, Буњевци и Шокци у Бачкој, Барањи и Лици, Београд 1899, 76; Владимир Ћоровић, Историја Срба, књ.2, Бероград 1985, репринт, 197-206)

${ }^{31}$ Алекса Ивић, Историја Срба у Војводини, 289, 491; Исти, Миграџије Срба у Славонију, 96.
} 
У време док су принц Лудвиг Баденски и други царски команданти тежиште ратних операција пренели у Србију и Ердељ, хрватско-славонско и босанско ратиште потиснуто је у други план. Турци су истина, у више махова, покушавали да врате изгубљену Славонију, па су 1691. стигли и до Осека, али су били одбијени, те су се ограничили на повремене пљачкашке походе преко Саве, који су доста успешно одбијани од посада царске војске и локалних народних команданата. То је било праћено час слабијим, час јачим, мигрирањем хришћанског становништва из Босне у Славонију. Умногоме је томе доприносила и глад у Босни тих година. ${ }^{32}$

Према истраживањима хрватског језикословца и етнографа Стјепана Павичића, после 1692. године и грађења одбрамбене линије на Сави, почело је „масовно сељење католика и православних на северну савску обалу“ и како наводи „Том приликом у десет, петнаест година прешло је ријеку Саву много тисућа тог народа [из Босне], православног, још много више него католика, те су се они настанили у многа села око Винковаца, Ђакова, Нашица, Ораховице, а поготово око Пожеге. Ти Хрвати и Срби испрва су настањивали углавном стара муслиманска насеља, а онда су постепено улазили и у она кршћанска која су им се нашла на путу“. ${ }^{33}$ Посредније доказе о тачности ове Павичићеве концепције налазимо у непосредним пописима Славоније с краја XVII века, у којима се између осталог наводи да су у Сибињ код Славонског Брода, одмах после протеривања Турака (1691/1692) дошли становници из Босне, а то се десило и у погледу села Свилаја када су и у њега пристигли 1692. пресељеници из Босне обеју вероисповести, које је пуковник Јован Фердинанд Киба претворио у своје граничаре. Годину дана касније (1693) католичко и православно становништво из Босне попунило је и славонско село Зденце, а 1695. насељени су на тај начин села Томинкут и Клокочевац. ${ }^{34}$ Тих година, пре 1698, поданике из Босне обеју вероисповести добио је и град Вуковар, у који их је превео капетан Пречлија, коме су они за ту услугу, милом, или силом, морали дати преко 60 комада ситне и крупне стоке. ${ }^{35}$ Према званичном извештају једне царске комисије од 19. фебруара 1694. која је упућена у Славонију, више хиљада лица (vihl Thausend Persohnen) прешло је из Босне, због глади (cogente fame) под аустријску власт. Они су од стране коморских службеника насељени у новоосвојене области између Дунава, Саве и Драве. ${ }^{36}$

Можда највећи миграциони талас српског становништва из Босне у време Великог бечког рата забележен је 1697. године. Према старим српским записима у „лето 1697. аго октомбрија 13 - аго приђоше Нјемци...и попленише Сарајево и прогнаше Христијане и Шокце преко Саве...и преселише нас у Славонију, Срем и

\footnotetext{
${ }^{32} \mathrm{O}$ томе поближе : Tade Smičilkas, nav.delo, passim.

${ }^{33}$ Stjepan Pavičić, Razvitak naselja u županijskom području, Županijski zbornik, Županja 1971, 30-36.

${ }^{34}$ Ivo Mažuran, Popis naselja i stanovništva u Slavoniji 1698. godine, Osijek 1988, 116, 138, 146, 166, 175-176.

${ }^{35}$ Исто, 47.

${ }^{36}$ Славко Гавриловић, Грађа за историју Војне границе у ХVIII веку, књ. I, (Банска крајина), Београд 1989, 20.
} 
Бачку. ${ }^{37}$ Ово је био поход аустрисјког принца, генерала Евгенија Савојског који се 1697. у јесен пробио до Сарајева (Врх Босне) и са собом повео „мноштво православних и римокатоличких породица“ које су насељене у Славонији. Према наводима хрватског историчара Смичилкаса после паљења Сарајева „кршћани бојећи се окрутне освете турске проврише под окриље царске војске. Много народа кршћанскога пређе сада у Славонију и преко Славоније у Угарску. Принц је дапаче желио све кршћане извући из Босне. Приближућа се зима и лоши путеви разбију ову основу принчеву“. ${ }^{38}$ Коликог је обима била ова миграција српског становништва из Босне најбоље сведочи молба српског патријарха Арсенија III Чарнојевића Комисији за уређење Славоније, да му се доделе три опустела предела ради насељавања 20.000 Срба, који су из Босне избегли у Угарску. ${ }^{39}$ Према наводима хрватског историчара Иве Мажурана, после упада принца Савојског у Босну већина миграната одабарала је за своја нова станишта околину Церника, Пакраца, Дарувара, Пожеге, Воћина и Ораховице, односно данашње Западне Славоније. $^{40}$

Велику масу српског народа насељену у Славонију из Босне за време похода принца Евгенија Савојског помиње и врсни српски историчар Рајко Веселиновић који је констатовао да „сеоба нашег народа из Босне 1697. године спада у једно од највећих пресељавања становништва“. Највише се иселило из ранијег дервентског среза, под вођством свештеника и пароха. Тако је рецимо свештеник Андрија извео из Дубочца 2.100 душа, парох Михаило из Велике, повео је из Дервенте 23.000 душа, Јован Леовчанин извео је из Мајевца 1.500 душа, док су из Модриче под вођством Илије из Дубочца, Јосифа Равечанина и Симона, отишли сви парохијани, укупно 49.000 лица, односно близу 10.000 породица. ${ }^{41}$

Мажуранови поуздани подаци из поменутог пописа Славоније, извршеног 1698, показују да је добар део славонских насеља 1697. године, по походу принца Евгенија Савојског, добио нове становнике из Босне. Наведена су следећа насеља: Нашице, Клокочевац, Пољанаци, Селна - насељени католици; Билишевци, Ново село, Чечавац - Срби и католици; Вучјак - Срби; Кућани и Јакупље - Срби; Скендеровци, Куновци - католици; Брђани, Пасковци, Разна, Кујник - Срби; Слобоштина, Черљенци, Милановци - Срби; Какочак - Срби односно „Власи“; Подборје (Дарувар) - 28 српских породица; Бастаји - 13 српских породица; Кореничани - 18 српских породица; Бела Стена -6 српских породица. ${ }^{42}$

\footnotetext{
37 Љубомир Стојановић, Стари српски записи и натписи, књ. IV, Сремски Карловци 1923 (репринт издање : Београд 1986), 223 - 224.

${ }^{38}$ Tade Smičilkas, Dvijesto oslobođenja Slavonije, Zagreb 1891, 169 - 170.

${ }^{39}$ Према грађи коју је објавио Славко Гавриловић, види се још прецизније, да се патријарх 31 . децембра 1697. обратио Царској дворској комори у Бечу ради додељивања три пустаре у Барањи ради насељавања 20.000 Срба из Босне. (Славко Гавриловић, Извори о Србима у Угарској с краја XVII и почетком XVIII века, књ. II, 309 - 310)

${ }^{40}$ Ivo Mažuran, Popis naselja i stanovništva u Slavoniji, 41.

${ }^{41}$ Рајко Веселиновић, нав.дело, 567.

${ }^{42}$ Ivo Mažuran, nav.delo, passim.
} 
Босанских српских избегличких породица било је и у Источној Славонији, односно западном Срему, од тога : у Белом Брду - 7; Тењу - 8; Трпињи - 6, Валпову и Кућанцима - 1 породица. ${ }^{43}$ За претпоставити је да их је било и у Даљу, за који немамо података из овог времена.

Излагање о миграцијама у време Великог бечког рата закључићемо најмеродавнијим дописом Дворског ратног савета Угарској дворској канцеларији у Бечу од 5. фебруара 1700. године, у коме се каже да је у току тог рата у хрватске крајине (Карловачки и Вараждински генералат) прешло много „влашког или расијанског“ народа, односно много више него што Крајина може прихватити. Пошто само део миграната може бити задржан у Крајини, све друге треба преселити у новостечене области Угарске и Славоније, које су великим делом опустеле, а где би им било боље него њиховим сународницима који су остали под влашћу Турака. ${ }^{44}$

Као што се из свега реченог може закључити, број миграната из Босне у Хабзбуршку монархију у току Великог бечког рата износио је једно небројено мноштво. Ако изузмемо Велику сеобу Срба из 1690. и процене које се крећу између 50.000 до 120.000 људи у њој, босанске миграције су такође веома бројне и сигурно износе више десетина хиљада што православних, што католика, који су својом бројношћу попунили новоослобођене славонске области, а својом, у великој мери, будућом граничарском службом у XVIII веку, допринели даљем јачању Монархије у борби против Турске.

\section{Извори и Литература :}

Гавриловић, Славко, Грађа за историју Војне границе у XVIII веку, књ. I, (Банска крајина), Београд 1989.

Гавриловић, Славко, Извори о Србима у Угарској с краја XVII и почетка XVIII века, књ. II, Београд 1990.

Hoff, Kriegs Archiv, Hoff Finanz Ungarn, (HKA, Hoff Ungarn), r. $\mathrm{N}^{0} 325$, September 1688, fol.230233

Magyar Orsagos Leveltal (MOL), A - 21, Litterae Palatinorum, cs. 2.

Веселиновић, Рајко, Народни покрети и устании, у Историја српског народа, књ. III, Београд 1993.

Gavrilović, Slavko, Prilog istoriji seljačkih nemira u Pokuplju od kraja XVII do kraja XVIII stoleća, Historijski zbornik, br. XVI, Zagreb 1963.

Грбић, Манојло, Карловачко владичанство, књ. I, (репринт издање), Топуско 1990 .

Дабић, Војин, Банска крајина 1688-1751, Београд-Загреб 1984.

Дабић, Војин, Војна крајина, Карловачки генералат (1530 - 1746), Београд 2000.

Димић, Жарко, Велики бечки рат и Карловачки мир, Београд 1999

\footnotetext{
${ }^{43}$ Исто, 64-70, 77, 80.

${ }^{44}$ Славко Гавриловић, Извори о Србима, књ. II, 400 - 401.
} 
Ердељановић, Јован, O пореклу Буњеваиа, Београд 1930.

Иванић, Иван, Буњевци и Шокии у Бачкој, Барањи и Лици, Београд 1899.

Ивић, Алекса, Историја Срба у Војводини, Нови Сад 1996 (поновљено издање) .

Ивић, Алекса, Миграиије Срба у Славонију током 16, 17. и 18. столећа, Суботица 1926.

Ивић, Алекса, Миграиије Срба у Хрватску током 16, 17. и 18. столећа, Суботица 1923.

Kaser, Karl i saradnici, Popis Like i Krbave 1712. godine, Prosvjeta, Zagreb 2003.

Ковачевић, Душко М., Старо Хопово-манастир Светог Пантелејмона, Београд 2003.

Lopašić, Radoslav, Oko Kupe i Korane, Zagreb 1895.

Lopašić, Radoslav, Spomenici hrvatske krajine, knj. III, Zagreb 1889.

Mažuran, Ivo, Popis naselja i stanovništva u Slavoniji 1698. godine, Osijek 1988.

Микавица, Дејан, Гавриловић, Владан, Васин, Горан, Знаменита документа за историју српског народа (1538-1918), Нови Сад 2007.

Микавица, Дејан, Српско питање на угарском сабору, Нови Сад 2011.

Pavičić, Stjepan, Razvitak naselja u županijskom području, Županijski zbornik, Županja 1971.

Поповић, Душан Ј., Историја Срба у Војводини, къ. II, Нови Сад 1990.

Поповић, Душан Ј., Племсто, Војводина II, Нови Сад, б. Г.

Поповић, Душан Ј., Слика Војводине у 18 веку, Војводина II, Нови Сад, б. г.

Радека, Милан, Кордун у прошлости, Загреб 1989.

Радонић, Јован, О сеоби Буюеваиа у Суботииу 1687. године, Глас САНУ, CCXIV, Одељење друштвених наука, књ. 3, Београд 1954.

Самарџић, Никола, Франиуска и Турска (1687-1691), Београд 1992.

Smičilkas, Tade, Dvijestogodišnjica oslobođenja Slavonije, Zagreb 1891.

Станојевић, Глигор, Србија у време Бечког рата, Београд 1976.

Стојановић, Љубомир, Стари српски записи и натписи, књ. IV, Сремски Карловци 1923 (репринт издање) Београд 1986.

Tkalac, Krunoslav, Porijeklo i kretanje Šokaca iz Bosne prema sjeveru preko Save i Dunava, Županijski zbornik, sv. 3, Županja 1971.

Ћоровић, Владимир, Историја Срба, књ.2, Бероград 1985, репринт.

Czoernig Freiherr, Karl, Etnographie der Oesterreichischer Monarchie, II Band, Wien 1857. 


\title{
MIGRATORY MOVEMENTS OF SERBIAN NATION IN BOSNIA DURING THE GREAT VIENNA WAR
}

\begin{abstract}
Summary
At the time of the Great Vienna War (1683-1699) there were large migration flows in the Balkans. The paper explains the migrations of the Orthodox (Serbian) and the Catholic population from Bosnia, which remained under the Turkish rule, to the newly liberated areas of Croatia and Slavonia. If the Bosnian migrations from this period are analzyed as a separate segment, it could be concluded that several tens of thousands of the Orthodox and Catholics migrated from Bosnia to Croatia and Slavonia, what largely resulted in filling this empty territory, strengthening the defensive power of the Habsburg Monarchy in relation to Turkey.
\end{abstract}

Keywords: Habsburg Monarchy, Great Vienna War, Serbs, Bosnia, Croatia, Slavonia, Catholics, migrations. 